University of Nebraska - Lincoln

DigitalCommons@University of Nebraska - Lincoln

1981

\title{
EFFECTS OF REDUCED TILLAGE AND MULTIPLE CROPPING ON PLANT DISEASES
}

Donald R. Sumner

Ben Doupnik Jr.

M. G. Boosalis

Follow this and additional works at: https://digitalcommons.unl.edu/plantpathpapers

Part of the Other Plant Sciences Commons, Plant Biology Commons, and the Plant Pathology Commons

This Article is brought to you for free and open access by the Plant Pathology Department at DigitalCommons@University of Nebraska - Lincoln. It has been accepted for inclusion in Papers in Plant Pathology by an authorized administrator of DigitalCommons@University of Nebraska - Lincoln. 


\section{TILLAGE AND MULTIPLE CROPPING ON PLANT DISEASES}

\section{Donald R. Sumner}

Department of Plant Pathology, University of Georgia, Coastal Plain Station, Tifton, Georgia 31793

Ben Doupnik, Jr.

Department of Plant Pathology, University of Nebraska, South Central Station, Clay Center, Nebraska 68933

\section{G. Boosalis}

Department of Plant Pathology, University of Nebraska, Lincoln, Nebraska 68583

\section{INTRODUCTION}

In the past, tillage research on plant diseases was concerned primarily with practices that buried plant residues in single-crop production systems. The burial of plant debris to destroy pathogens is an ancient agricultural practice (34). Each crop was tested as a single entity, and most crop rotations were based on one crop per year. Interest in notill and conservation tillage systems and multiple cropping has increased in the past two decades because of the scarcity and increased cost of fossil fuels, periodic world food shortages, and the concern over soil erosion $(73,110)$. These concerns are of such paramount importance in many countries that total crop production systems may have to be altered to meet the needs of a rapidly changing world.

For this review the following definitions from Andrews \& Kassam are used (5). 
Multiple cropping: The intensification of cropping in time and space such as growing two or more crops on the same field in a year.

Sequential cropping: Growing two or more crops in sequence on the same field per year where the succeeding crop is planted after the preceding crop is harvested (double cropping, triple cropping, and quadruple cropping).

Intercropping: Growing two or more crops simultaneously on the same field.

Monocropping: Growing one crop on a field each year.

Monoculture: The repetitive growing of the same crop in the same land.

More detailed explanations of other terms used in multiple cropping are given in other papers $(5,7,74,75,85)$.

Tillage in agriculture is the changing of soil conditions for crop production (2). Definitions used for tillage practices are as follows:

Conventional tillage: Traditional tillage system, which typically begins with a primary deep tillage operation followed by some secondary tillage for seedbed preparation (7).

Conservation tillage: Any tillage practice that reduces loss of soil or water compared to unridged [soil is not mounded into a specific configuration (2)] or clean tillage (85).

Minimum tillage: That minimum amount of tillage required to create the proper soil condition for seed germination and plant establishment (85).

Notillage, zero tillage: A method of planting crops that involves no seedbed preparation other than opening the soil for the purpose of placing the seed at the intended depth. This usually involves opening a small slit or punching a hole into the soil. There is usually no cultivation during crop production. Chemical wead control is normally used (85).

Chiseling: A tillage operation in which a narrow tool is used to break up hard soil. It may be performed at other than the normal plowing depth (2).

Plowing: A primary tillage operation which is performed to shatter soil with partial or complete soil inversions (2).

Subsoiling: Tillage of subsurface soil, without inversion, below $406 \mathrm{~mm}$, to break up dense layers that restrict water movement and root penetration $(2,85)$.

Reduced tillage systems have been established in many areas of the world and will become increasingly important in other areas where soil moisture 
and erosion impact on crop production (11). Continuing expansion of conservation tillage throughout the world relates to soil erosion, double and opportunity cropping, energy limitations, and drought. Although much progress has been made in refining and in improving conservation tillage systems for specific crops and environments, many aspects need further improvement. These include more efficient planting machinery, the degree of weed control necessary, control of diseases and pests associated with crop residues, crop row spacing, and breeding of varieties adapted to the new environment.

\section{TEMPERATE CLIMATES}

\section{Humid Regions}

MONOCROPPING Corn frequently is grown in monocrop systems in the central United States, and much of the acreage is now grown under various types of minimal tillage and conservation tillage systems. Several foliar pathogens of corn are known to survive in corn residue in minimal tillage systems. These pathogens include Helminthosporium turcium and H. maydis, which induce northern and southern corn leaf blight, respectively (12,14); Phyllosticta maydis, which induces yellow corn leaf blight (6); Physoderma maydis, which induces brown spot (23); Colletotrichum graminicola, which induces anthracnose (12,73); and Cercospora zeae-maydis, which induces gray leafspot $(39,76)$. Most of these diseases are more severe in minimal tillage than when corn debris is buried by plowing, but anthracnose stalk rot is not controlled by plowing (106). Tillage practices may also influence the severity of sooty stripe of sorghum, caused by Ramulispora sorghi, as the fungus overwintered in Nebraska in plant debris on the soil surface (65). Stunting may occur in corn following small grains in a stubble-mulch (minimal tillage) system (55). The condition is probably caused by phytotoxic decomposition products from decaying residues, but it is not known whether soilborne pathogens and bacteria have a role in the retardation of plant growth. Reduced tillage decreases soil temperatures in the spring and early summer $(24,104)$, and may retard seed germination and seedling development and be conducive to damping-off and root diseases induced by soilborne pathogens favored by low temperatures. Thus, the importance of moving residues away from emerging plants is obvious (12).

In wheat, minimal tillage has decreased the incidence of take-all, caused by Gaeumannomyces graminis var. tritici $(18,40)$; decreased $(18,28)$ or had no effect (40) on eyespot, caused by Pseudoscercosporella herpotrichoides; and did not influence the incidence of sharp eyespot caused by Rhizoctonia solani, and brown footrot caused by Fusarium spp. (40). In the winterrainfall wheat area of the northwestern United States, take-all is signifi- 
cantly more severe but eyespot less severe in notill than in conventional tillage systems (27). Why yields are less in notill systems has not been determined. The decrease in yields can be largely overcome by soil fumigation, and Pythium spp. and phytotoxins are suspected as causes of increased root rots in notill systems (27). Moving the straw away from the seed to the interrow area at planting may reduce the detrimental effects of straw by allowing for proper, nonelevated, crown-depth development (25). The incidence of Cephalosporium stripe caused by Cephalosporium gramineum was reduced by plowing in Michigan. Populations of the pathogen remained high on infested straw beneath the soil surface during the first autumn, but the straw was degraded and populations of the pathogen declined to very low numbers by the second autumn. In contrast, where host residues remained undisturbed on the soil surface the fungus survived saprophytically and produced conidia for at least three years (107). In the USSR, deep tillage $(25-30 \mathrm{~cm})$ reduced root rot caused by Cochliobolus sativus in wheat following pea, clover, or corn (100).

Notillage practices gave variable results with vegetables. In Maryland, yields of early seeded tomatoes were enhanced by notill, and yields of snapbean, lima bean, watermelon, and sweet corn were comparable to conventional tillage (9). In Kentucky, stands of cucumber and sweet corn were sometimes reduced, but survival of tomato and pepper were not influenced by notill. In Tennessee snapbean and lima bean were grown in notill, reduced tillage (disk or powdered harrow), and conventional tillage following barley. Tillage did not affect yield of snapbean, but lima bean yields were highest with conventional tillage $(50,61)$. Unfortunately, data on plant diseases were not taken in these studies. In North Dakota, plowing wheat residue $26 \mathrm{~cm}$ deep increased stem and stolon lesions on potato caused by Rhizoctonia solani compared with disking or plowing $13 \mathrm{~cm}$ deep. Organic matter on the surface soil apparently inhibited the survival or infection potential of $R$. solani (37). Other research indicates that $R$. solani survives primarily in colonized plant debris, and the fungus does not survive below $15 \mathrm{~cm}$ in soil $(13,68)$. In contrast, sclerotia of Sclerotinia sclerotiorum will survive deep plowing. Plowing resulted in the burial of sclerotia and less lettuce drop compared with disking, but a second moved the sclerotia back up to the soil surface (56). Leaving plant residues on the soil often leads to increased stunting, root rot, and damping-off in vegetables $(26,45)$; but research on the influence of specific tillage practices on plant diseases of different vegetables is generally lacking.

In perennial crops, tillage may result in increased root damage and disease. Verticillium wilt was less in hop when notill plus herbicides were used than when conventional tillage practices were used in fields with a high incidence of the disease. This reduction probably was caused by the eradica- 
tion of alternative weed hosts, less root damage, changed patterns of root distribution, and the inhibiting action of the herbicide on root growth in surface soil. The last of these effects probably resulted in less contact between roots and surface-borne inoculum. In contrast, there was a tendency for notill to increase disease when the wilt incidence was low, possibly because of differential effects on nitrogen metabolism or availability (81).

Little research has been done on the influence of tillage on nematodes, viruses, or bacterial pathogens. In Great Britain, plowing reduced population of migratory parasitic nematodes compared with notill in continuously cropped wheat (29). In Iowa, on the other hand, populations of plant parasitic nematodes in corn were usually greater in notill ridge (mounds in a specific configuration) plots than in spring- and fall-plowed plots (101). No data were taken on the effects of the different population densities on root damage in either study, but corn yields were lower in notill than in plowed plots. Several bacterial pathogens overwinter in plant debris on the surface but not in buried plant debris. These pathogens include Pseudomonas glycinea, which induces bacterial blight of soybean (31); P. phaseolicola, which induces halo blight of snapbean (63); Xanthomonas malvacearum, which induces bacterial blight of cotton (17); and Corynebacterium nebraskense, which induced Goss's bacterial wilt and blight of corn (79). Several bacterial pathogens do not survive well in soil. Others (Erwinia spp., Pseudomonas soft rotters) are ubiquitous in soil $(19,20)$, but the influence of different tillage practices on bacterial disease losses has not been determined.

DOUBLE CROPPING The most common double-cropping system in the temperate climates of the United States is small grain followed by soybean; much notill is used on this acreage. In Arkansas, soybean seedling diseases induced by Sclerotium rolfsii and $R$. solani increased in double cropped plots compared with conventionally planted soybeans, but seed treatments controlled the diseases (30). In Delaware, notill increased populations of Fusarium species in soil, but there were no differences in the incidence of wilt induced by $\boldsymbol{F}$. oxysporum in soybean between notill and conventional tillage. (35).

Increased damage to vegetables occurs frequently when two crops of vegetables are grown each year. In a 14-year study in Connecticut, yields of lettuce, carrot, sweet corn, spinach, beets, and cabbage were less in more intensive rotations of two successive crops of vegetables per year compared with vegetables alternating with "green manure" crops of rye, vetch, or soybean (45). Lettuce is sensitive to decaying crop residues, and root disease and stunting were reported in California, Wisconsin, and New York on intensively cropped lettuce $(3,38,72)$. 
Intercropping is rare in temperate climates, but a mixed cropping of pea and barley, oats, or wheat in Canada reduced Ascochyta stem and pod diseases of pea and produced the same or increased yields of pea and small grains when compared with monocropping (48).

\section{Semiarid and Arid Climates}

ECOFALLOW Ecofallow is a conservation cropping system that has gained widespread acceptance in the central Great Plains of the United States (32). Ecofallow is defined as a system for controlling weeds with herbicides and sweep (wing-shaped cultivation shovel) tillage and conserving soil moisture in a crop rotation with minimum disturbance of crop residue and soil (33). The system is used with either a three-year rotation or winter wheat-grain sorghum or corn-fallow, or a two-year rotation of winter wheat-fallow. The three-year system differs from many reduced tillage practices in that one crop is planted directly into the residue of a different crop rather than into the residue of the same crop.

Compared with conventional tillage ecofallow dramatically decreased the incidence of stalk rot of grain sorghum induced by Fusarium moniliforme, (32). Increased storage of soil moisture with ecofallow is undoubtedly an important factor in the lower incidence of stalk rot. In addition the wheat residue results in a lower, more constant soil temperature in grain sorghum planted in ecofallow. Thus, the growing conditions are more favorable in ecofallow and plants are less vulnerable to fungi that induce stalk rot (12).

Foliage diseases were not a problem under the three-year ecofallow system. In a two-year ecofallow experiment with wheat following wheat, tan spot reduced by Pyrenophora trichostoma and leaf blight reduced by Septoria tritici increased to the point of concern (32). The tan spot pathogen overwinters on surface residue from the infected crop, but incorporating infested residue into the soil prevents the formation of the overwintering perithecial stage and destroys the pathogen (12). The increase in foliar diseases under the wheat monoculture system of ecofallow indicates the importance of using two different crops to help prevent disease buildup.

OTHER TILLAGE PRACTICES In a wheat monoculture in semi-arid Canada, yields were not affected by shallow plowing $(10-15 \mathrm{~cm})$ compared with a one-way disk minimal tillage system (54), but common root rot induced by $C$. sativis and $F$. culmorium was less abundant in the seodling stage but not at maturity. Large amounts of rape residue reduced common root rot of small grains compared with less residue but yields were less where rape residues were greatest (41). The variability of spore germination of $H$. sativum in response to its environment and particularly to nutrition may 
partly explain the inconsistency of crop rotations and soil amendments in alleviating common root rot of wheat and other diseases (12). The severity of snow mold, caused by Typhula idahoensis, was not influenced by tillage practices in Idaho. Sclerotia survive burial, and plowing might bring up dormant sclerotia (42), as suggested earlier for sclerotia of Sclerotinia sclerotiorum in Australia (56).

Subsoiling is beneficial in reducing soil compaction and decreasing the severity of bean root rot induced by $F$. solani $\mathrm{f}$. sp. phaseoli. Increased yields appeared to result by counteracting the effects of the disease through increased rooting depth and volume, and through greater regeneration of roots as the season progressed (22). The fungus was distributed throughout the plow layer (20-30 cm depth) but seldom found in the subsoil $(33-41 \mathrm{~cm}$ depth). In noninfested fields, and in a Fusarium-infested field containing barley residues, many roots penetrated to a depth of $1 \mathrm{~m}$ or more. In contrast, roots of most plants penetrated the subsoil only a few centimeters in Fusarium-infested fields (21).

There are only a few reports on the effects of reduced tillage on plant diseases in irrigated farmland. Most such research has been with overhead irrigation. A five-year study completed recently at the University of $\mathrm{Ne}$ braska South Central Station evaluated the effects of six tillage systems (including conventional and notill) on amount of fertilizer and irrigation water, production costs, energy requirements, pest control (diseases, weeds, insects), and grain yield in corn monoculture using furrow irrigation (B. Doupnik, unpublished data). There were no significant differences in pest control and grain yields among the tillage systems, but there were differences in energy requirements and production costs.

\section{SUBTROPICAL CLIMATES}

\section{Sequential Cropping}

In the subtropical regions of the world two or more crops can be grown in sequence without danger of frost for approximately 200 to 300 days, and if winterhardy forage crops, cereals, or vegetables are used, three or more crops can be grown each year (94). Some sequential cropping systems studied at the Georgia Coastal Plain Station from 1971 to 1980 are listed in Tables 1 and 2.

\section{FOLIAGE PATHOGENS}

Fungi Helminthosporium maydis survived on surface corn residues in disked and rotary-chopped corn monoculture, but not in residues buried by plowing; southern corn leaf blight was more severe in disk-harrowed and 
Table 1 Multiple cropping sequences studied at the Coastal Plain Station, 1971 to 1980 (90-95)

$\begin{array}{ll} & \text { Number of } \\ \text { Annual sequences } & \\ \text { Turnip-corn snapbean } & 4 \\ \text { Turnip-corn-turnip } & 4 \\ \text { Turnip-peanut-snapbean } & 4 \\ \text { Turnip-peanut-turnip } & 4 \\ \text { Snapbean-soybean-cabbage } & 4 \\ \text { Turnip-cucumber-southern pea-turnip } & 6 \\ \text { Turnip-corn-southern pea } & 3 \\ \text { Corn-soybean } & \\ \text { Two-year sequences } & 1.3 \\ \text { Cucumber-squash-cabbage-cucumber } & 1.6 \\ \text { Cucumber-cucumber-cucumber } & 6 \\ \text { Sweet corn-soybean-wheat-soybean-spinach } & 6 \\ \text { Turnip-peanut-cucumber-turnip-cucumber-soybean } & 3 \\ \text { Field corn-soybean } & 3 \\ \text { Squash-soybean field corn-snapbean } & 3 \\ \text { Field corn-snapbean-squash-soybean } & \end{array}$

rotary-chopped notill plots than in plowed plots (96). Deep-plowing also reduced the incidence of sorghum downy mildew and increased the yield of a susceptible sorghum cultivar compared with conventional plowing (103). When a spring crop of lima bean was followed immediately by a summer crop of lima bean, stem anthracnose was so severe that the second crop had to be abandoned. The plants in the second crop were infected with Collectotrichum truncatum soon after emergence, even though residues from the first crop were buried by plowing, and the disease could not be controlled once plants were infected (D. R. Sumner and D. Smittle, unpublished data). Leafspots of turnip were more severe in intensive cropping systems when both fall and spring crops of turnips were grown for leafy greens each year in contrast to growing only one crop of turnip each year in the spring. Since no winter crop was used, leafspot pathogens apparently survived from the fall crop on plant debris, even though the soil was plowed each year before turnip was planted in the spring (91). Continuous cropping of two to three crops of cucumber per year has been practiced in the southeastern USA, but gummy stem blight, induced by Mycosphaerella citrullina, may be severe if other crops are not inserted between cucumber crops to reduce the primary inoculum (83).

In multiple-cropped southern pea, plowing reduced Cercospora leafspots and rust, and decreased premature defoliation compared with harrowing (97). 
Table 2 Multiple cropping sequences grown on Lakeland sand under centerpivot sprinkler irrigation in Tift county, Georgia

\begin{tabular}{|c|c|c|c|c|}
\hline \multirow{3}{*}{$\begin{array}{c}\text { Year } \\
-j\end{array}$} & \multicolumn{4}{|c|}{ Sequences } \\
\hline & 1 & 2 & 3 & 4 \\
\hline & $\begin{array}{l}\text { Sweet corn } \\
\text { Cucumber } \\
\text { Turnip }^{\mathbf{a}}\end{array}$ & $\begin{array}{l}\text { Peanut } \\
\text { Rye }\end{array}$ & $\begin{array}{l}\text { Field corn } \\
\text { Field corn } \\
\text { Rye }\end{array}$ & $\begin{array}{l}\text { Peanut } \\
\text { Wheat }\end{array}$ \\
\hline 2 & $\begin{array}{l}\text { Tomatob } \\
\text { Lima bean } \\
\text { Rye }\end{array}$ & $\begin{array}{l}\text { Sweet corn } \\
\text { Southern pea } \\
\text { Spinach }\end{array}$ & $\begin{array}{l}\text { Field corn } \\
\text { Field corn } \\
\text { Sugar beet }\end{array}$ & $\begin{array}{l}\text { Soybean } \\
\text { Rye }\end{array}$ \\
\hline 3 & $\begin{array}{l}\text { Snapbean } \\
\text { Sweet corn } \\
\text { Vetch }\end{array}$ & $\begin{array}{l}\text { Cucumber } \\
\text { Soybean }\end{array}$ & $\begin{array}{l}\text { Field corn } \\
\text { Sweet corn } \\
\text { Vetch }\end{array}$ & $\begin{array}{l}\text { Tomato } \\
\text { Peanut } \\
\text { Spinach }\end{array}$ \\
\hline
\end{tabular}

\footnotetext{
a Leaves were harvested for greens.

b Tomatoes were transplanted and grown for fruits.

c Tomatoes were direct seeded and grown for transplants.
}

In China, the removal of all leafy plant parts immediately after harvesting each crop, the heavy use of organic fertilizers, and extensive rice culture that involves flooding of fields apparently reduce the survival of foliage pathogens in multiple cropping. Nevertheless, double or triple cropping systems of wheat with rice or corn, flooding, and organic amendments have not eliminated scab caused by $F$. roseum 'graminearum' in wheat. All three crops serve as hosts for the pathogen, and airborn ascospores are produced in perithecia on each host. Certain foliage diseases of sorghum and corn are also problems (49).

Bacteria and viruses Little information is available on the influence of tillage systems and multiple cropping on foliage diseases induced by bacteria and viruses. All et al (1) found that virus diseases in corn were increased slightly by notill compared with conventional tillage, but the overall incidence of virus disease was low. Notill induced a significant increase in the total leafhopper population and the amount of johnsongrass, an overwintering host reservoir for maize chlorotic dwarf and maize dwarf mosaic viruses. Increase in the abundance of weeds that are alternate hosts for viruses is a potential hazard in most notill systems. More research is needed to determine whether tillage systems influence the incidence and severity of virus diseases.

In Georiga, Xanthomonas campestris, which induces black rot in cabbage, survived 8 months in buried cabbage stems, but only 42 days in infested soil (78). Soil is manipulated more frequently in multiple cropping systems than in monocrop systems, and it is possible that infected cabbage 
stems might decay more rapidly in multiple-cropping systems and allow more frequent cropping of crucifers.

\section{SOILBORNE PATHOGENS}

Fungi Researchers have long advocated the burial of plant residues by plowing to control soilborne pathogens in subtropical crops. One of the earliest and most successful examples of disease control by appropriate plowing and cultivation was the control of southern blight of peanut caused by Sclerotium rolfsii (16). Cultural practices developed to deprive the fungus of a food base from which it could launch an attack included shallow plowing $(13-18 \mathrm{~cm})$ to cover all organic debris, nondirting cultivation to prevent soil and debris from being thrown around the base of the plants, and controlling leafspots to prevent dead leaves from falling and accumulating to provide an energy source that enhances growth and infectivity of the pathogen (36). Southern blight is also controlled on tomato by deep plowing, as compared with disking (111).

This paradigm for successful control of southern blight is not valid for controlling other root diseases in multiple cropping systems. In four multiple-cropping sequences including snapbean and cowpea at the Coastal Plain Station, plant debris was frequently in contact with or adjacent to primary roots and hypocotyls of seedlings even though the soil was turned with a moldboard plow just before planting. Root diseases caused by Pythium spp. and $R$. solani were of slight to moderate intensity in snapbean following corn, peanut, or cabbage and $R$. solani caused moderate to severe root rot in cowpea following cucumber in two of four years (95). Seedling diseases also were severe in snapbean following cowpea with minimum tillage (87). In four years of tests with different tillage practices in multiple cropping systems at the Coastal Plain Station on both sand and loamy sand soils, deep plowing increased yields of snapbean following corn as compared with disking. In contrast, yields in subsoil-plant and subsoil-bed (minimum tillage treatments) plots were equal to yields in plowed plots. Differences in root disease severity among treatments were not significant, but populations of $R$. solani in $15 \mathrm{~cm}$ of topsoil frequently were lower at planting in plowed plots than in disked or subsoiled plots (D. R. Sumner, unpublished data). In cowpea, yield increases following sweet corn appeared to be related to less physical resistance of the soil to penetration by roots, and greater efficiency in nutrient use in deep plowed and subsoiled plots than in disked plots, rather than to differences in severity of root disease $(84,98)$. Similar results were found with subsoiling in cotton (43). Such factors may be more important than root disease in explaining yield responses of snapbean to different tillage practices. Nevertheless, root diseases of cowpea, snapbean, 
and lima bean may be limiting factors in multiple cropping systems, as evidenced by the consistent $50 \%$ increase in yields of cowpea by soil fumigation in the fall (93).

Root disease severity was less in turnip than in snapbean or cowpea in multiple cropping systems. There were no differences in root disease severity among spring crops of turnip, but root diseases were decreased and root growth was increased in turnip following corn compared with turnip following southern pea or peanut in fall crops (92).

Corn responds well to reduced tillage, and root diseases were minimal in multiple cropping systems. Yields were increased only $10 \%$ by soil fumigation (90), but recent research indicates that a sterile basidiomycete and $R$. solani (AG-2) may cause increased root diseases in multiple cropping systems $(88,89)$.

Minimum tillage concentrates residue in the top 10 to $15 \mathrm{~cm}$ of soil, and thus increases populations of soilborne pathogens associated with debris. The possibility of root necrosis and stunted, deformed plants from phytotoxins from decomposing residues $(15,71,72)$ is also increased by minimal tillage. On the other hand, populations of beneficial microorganisms and the biological control of pathogens could be enhanced by minimal tillage (8). Plowing reduced root disease severity and postemergence damping-off in one or more crops of lima bean, cowpea, snapbean, and corn, but not in squash, cucumber, tomato, turnip, spinach, grain sorghum, or soybean compared with minimum tillage. Populations of $R$. solani (primarily AG-4) were reduced in the top $15 \mathrm{~cm}$ of soil by plowing compared with minimum tillage treatments in 5 of 15 experiments, but tillage practices rarely influenced populations of other soil fungi (99). Plowing moves plant debris from the soil surface to a zone 10 to $30 \mathrm{~cm}$ deep, and brings soil from a lower depth to the surface. Populations of $R$. solani and Pythium spp. were also moved from the top $10 \mathrm{~cm}$ of soil to the subsoil by plowing. In contrast, minimum tillage concentrated plant debris and populations of $R$. solani and Pythium spp. in the top $10 \mathrm{~cm}$ of soil (Table 3). Populations of total fungi declined steadily from the 0 to $10 \mathrm{~cm}$ depth to the 30 to $40 \mathrm{~cm}$ depth in minimum tillage treatments. In contrast, plowing resulted in lower populations of fungi in the 0 to $10 \mathrm{~cm}$ depth but increased populations at the 10 to 20 and 20 to $30 \mathrm{~cm}$ depths, resulting in relatively uniform populations of total fungi in the plow layer (D. R. Sumner, unpublished data). In California, plowing effectively buried sclerotia of Sclerotium oryzae in continuous rice culture and caused an increased loss in viability of sclerotia compared with disking or rotovating (105).

Minimum tillage may be feasible in a wheat-soybean double-crop system in the subtropics, but wheat straw may have a deleterious effect on soybean growth. The reaction of different soybean cultivars to residue from different 
Table 3 Populations of Rhizoctonia solani and Pythium spp. in soil at different depths following different tillage implements*

\begin{tabular}{ccccc} 
& \multicolumn{4}{c}{ Tillage implement and depth } \\
$\begin{array}{ccccc}\text { Depth from } \\
\text { surface }(\mathrm{cm})\end{array}$ & $\begin{array}{c}\text { Moldboard } \\
\text { plow }(25-30 \mathrm{~cm})\end{array}$ & $\begin{array}{c}\text { In-row } \\
\text { subsoiler }(40 \mathrm{~cm})\end{array}$ & $\begin{array}{c}\text { Chisel } \\
(20-25 \mathrm{~cm})\end{array}$ & $\begin{array}{c}\text { Diskharrow } \\
(15 \mathrm{~cm})\end{array}$ \\
\hline \multicolumn{5}{c}{ Rhizoctonia solani, propagules per $100 \mathrm{~g}$ of soil } \\
$0-10$ & $8 \mathrm{ab}^{\dagger}$ & $37 \mathrm{a}$ & $36 \mathrm{a}$ & $51 \mathrm{a}$ \\
$10-20$ & $26 \mathrm{a}$ & $4 \mathrm{~b}$ & $8 \mathrm{~b}$ & $2 \mathrm{~b}$ \\
$20-30$ & $10 \mathrm{a}$ & $0 \mathrm{~b}$ & $0 \mathrm{~b}$ & $0 \mathrm{~b}$ \\
$30-40$ & $0 \mathrm{~b}$ & $0 \mathrm{~b}$ & $0 \mathrm{~b}$ & $3 \mathrm{~b}$ \\
& Pythium spp., propagules per gram of soil & \\
$0-10$ & $34 \mathrm{bc}$ & $49 \mathrm{a}$ & 8 & 20 \\
$10-20$ & $91 \mathrm{a}$ & $9 \mathrm{a}$ & 5 & 15 \\
$20-30$ & $57 \mathrm{ab}$ & $8 \mathrm{a}$ & 6 & 6 \\
$30-40$ & $4 \mathrm{c}$ & $0 \mathrm{~b}$ & 4 & 6 \\
\hline
\end{tabular}

* Soil samples were taken between rows 10 days after planting peanut in a sweet cornsoybean-turnip-peanut, two year, multiple cropping sequence.

f Numbers followed by the same letter are not significantly different according to Duncan's multiple range test $(P=0.05)$. No letters indicate no significant differences.

wheat cultivars is variable, suggesting that selection of wheat and soybean cultivars for double-cropping should be done in the environment where they will be grown (10).

In China, the practice of flooding fields for paddy rice and the use of organic fertilizers apparently greatly reduce the severity of diseases caused by soilborne pathogens in multiple cropping systems. Perhaps in vegetable crops the succession of crops is so varied and the growth period so short for a given crop that root pathogens may have little opportunity to intensify (49). However, Williams stated that root diseases were serious problems on cucurbits, tomatoes, and eggplant in vegetable communes near Kwiangsu, but were less serious in suburbs where vegetables were rotated with cereal crops (109).

Nematodes Fall plowing reduced populations of the root-knot nematode Meloidogyne incognita and the lesion nematode Pratylenchus zeae compared with no tillage, but the host crop planted had a greater influence on nematode population than did tillage practices (86). In corn following oats there were no differences in populations of lesion nematodes and spiral nematodes Helicotylenchus spp. between conventional tillage and no tillage (1). Subsoiling may reduce injury from nematodes (43), in a similar manner as previously discussed with soilborne pathogenic fungi, but in some instances subsoiling without using a nematicide was ineffective in increasing yields. In Georgia, populations of the lance nematode Hoplolaimus colum- 
bus increased significantly at the 33 to $46 \mathrm{~cm}$ depth after the second consecutive year of subsoiling, and soybean yields were not increased by subsoiling (69). In contrast, subsoiling reduced nematode injury and increased soybean yields in soil infested with $M$. incognita (70).

In four years of multiple cropping with six different sequences at the Coastal Plain Station (Table 1, first six sequences listed), none of the cropping systems prevented the increase of all pathogenic nematodes (94). All crops supported low to moderate levels of spiral and root-knot nematodes. Cucumber was most damaged by root-knot nematodes. Cropping systems including turnips and excluding corn suppressed populations of lesion nematodes more than other systems. In contrast, a nematicide was essential to control root-knot nematodes in an annual cropping sequence of turnipcorn-southern pea (77). However, inserting cultivars of corn or southern pea resistant to root-knot nematodes might reduce or eliminate the need for a nematicide. Cucurbits are very susceptible to root-knot nematodes, and in multiple cropping of cucumber and squash with film mulch and trickle irrigation, soil fumigation was essential to control nematodes and maintain high yields for three successive crops $(46,47)$.

In India, the number of nematodes following wheat, corn, and cotton in multiple cropping sequences was less than in monocultures of each crop, but data were not taken on the relationships of populations of nematodes to yields $(60)$.

Tillage is less influential on populations of nematodes than the cropping sequence. Nematode injury can be greatly reduced by selecting crops in a sequence, but nematicides are necessary to achieve high yields of susceptible crops such as cucurbits.

Growers in the southeastern United States use some of the multiple cropping sequences discussed previously, and they know that diversification of crops is necessary for disease control (64). It is impossible to study all of the possible combinations of crops that can be grown, because of the limitations of time and experiment station budgets. Nevertheless, it is imperative that more research be done on the influence of tillage and sequential cropping on plant diseases because growers worldwide must reduce energy use, while continuing to produce still more food and fiber per unit of land. The results could be disastrous if plant disease management is not an integral part of any intensive cropping experiments.

\section{TROPICAL CLIMATES}

\section{Sequential Cropping}

Sequential multiple cropping has long been common in the tropics, and in some countries fields have been multiple cropped continuously for centu- 
ries. Examples are continuous double cropping of swamp rice in Vietnam and in the Philippines (82), and multiple cropping of various vegetable and agronomic crops in China (49,109), the Middle East (62), Africa (66), and South America (74). Unfortunately, there is little published information on the influence of cropping systems and tillage practices on the incidence of plant disease. It is known that pathogens that survive in plant debris can provide inoculum to cause severe epidemics. A special effort is made in many countries not to grow crucifer crops frequently in a rotation because of black rot (108), downy mildew, and turnip mosaic virus (109). In Nigeria, it is recommended that yams not be grown on the same site more than once every four years in multiple cropping systems because of nematodes that disfigure the skin and reduce yields (4). In contrast, root rot caused by $R$. solani was as severe in cowpea following rice as in continuous cowpea (44). In the arid climate of Sudan, Xanthomonas malvacearum in infested debris was a threat to the next cotton crop, but in the wetter climate of Tanzania the pathogen barely survived between cotton crops in surface debris. Since many bacterial pathogens survive in debris but not in soil, reduced tillage might increase the incidence of bacterial diseases (80).

Ratoon cropping, the cultivation of crop regrowth after harvest, is practiced in surgarcane, sorghum, cotton, banana, pineapple, rice, ramie, and other crops (75). Virus diseases of rice and sorghum and bacterial blight and leaf crumple virus in cotton have increased with ratoon cropping $(67,75)$. In sugarcane, Pythium root rot, nematodes, and viruses have been associated with ratoon stunting disease and yield decline. Other diseases reported to cause severe losses in ratoon cropping of sugarcane are chlorotic streak, Fiji disease, sugarcane mosaic, and sugarcane smut (75).

\section{Intercropping}

Vegetables and field crops are intercropped throughout the tropics in many countries of Central America (74), Africa (66), and Asia (109). In Africa, the most widespread cropping system is mixed intercropping in compound farms (66). However, we are unaware of any research on the influence of intercropping on plant diseases in Africa.

In China, intercropping of vegetables maximizes land use and localizes development and spread of some foliar and soilborne pathogens. Common intercrop systems include such widely divergent crops as cabbage, eggplant, cucumber, yard-long beans, and celery. An exception is the intercropping of sequential overlapping rotations of crucifers (Chinese cabbage, leaf mustard, cabbage, and cauliflower) in South China, resulting in increases of turnip mosaic virus, bacterial soft rot, and downy mildew (109).

The most extensive research on plant diseases in intercropping systems 
was done in Costa Rica by Moreno \& Larios with cassava, bean, corn, cowpea, sweet potato, and plaintain (51-53, 57-59). Compared with a monoculture of cassava, intercropping bean with cassava reduced the severity of powdery mildew, but had no effect on scab, rust, and Cercospora leafspots of cassava. Cassava also reduced the severity of angular leaf spot in bean. This mutual benefit may be one of the reasons why cassava-bean intercropping is used widely by small farmers in Costa Rica (59). In contrast, corn with cassava increased the severity of powdery mildew but decreased the severity of scab in cassava. Sweet potato with cassava, or corn and sweet potato with cassava both reduced the severity of dieback caused by Colletotrichum sp., but the disease was decreased in all systems by increased potassium fertilization and weed control (59).

Compared with a bean monoculture, corn intercropped with bean reduced the severity of rust on bean whereas using sweet potato and cassava as an intercrop increased rust. In contrast, corn increased angular leafspot, while sweet potato and cassava decreased angular leaf spot.

Cowpea viruses are major problems in Central America, and intercropping cowpea with either cassava or plaintain reduced the incidence of cowpea mosaic virus and cowpea chlorotic virus, compared with a cowpea monoculture. In contrast, intercropping with corn was ineffective. The viruses are transmitted by beetles, and there was a positive correlation between the activity of the vectors and the percentage of plants with virus infection. The beetles were also less active under low light intensity, possibly explaining the decreased incidence of virus infection in cowpea grown under a cassava or plaintain canopy. Cowpea yields were reduced $60 \%$ because of less light, but research on growing cowpea under different degrees of cassava defoliation may result in acceptable cowpea yields (59). All three intercrops decreased the severity of Asochyta leafspot and the onset of an epidemic of powdery mildew of cowpea. However, intercropping did not reduce the severity of Cercospora leafspot of cowpea, and in the Philippines intercropping corn with mungbean did not reduce the severity of Cercospora leafspot of mungbean (44).

Some suggested effects of intercropping on pathogens and disease development are influence on spore dissemination, modification of the microenvironment (humidity, light, free moisture, temperature, air movement), and differences in nutrient uptake in an intercropping system compared with a monoculture, because of a more diversified root system $(52,66,102)$. Research on the influence of intercropping on plant diseases is in its infancy. More emphasis should be given to the influence of intercropping on plant disease, as intercropping is one of the most widely used systems of farming in the tropics. 


\section{CONCLUSIONS}

Conservation tillage and minimum-tillage practices may increase, decrease, or have no effect on plant diseases. Leaving plant debris on the surface or partially buried in the soil may allow numerous pathogens to overwinter, or survive until the next crop is planted, but conditions favorable for biological control of plant pathogens may also be increased $(8,12,27)$. Tillage practices directly influence physical and chemical properties of the soil, soil moisture and temperature, root growth and nutrient uptake, and populations of vectors of plant pathogens. These factors in turn may influence the viability and variability of plant pathogens and the susceptibility or resistance of the host.

Tillage practices may indirectly influence plant diseases by causing changes in the kind, rate, and time of fertilizer application; pesticide use; plant spacing; irrigation; and other cultural practices. Any change in the soil or plant canopy environment may influence the development of epidemics. There are enough conflicting reports in the literature, however, to indicate that the potential influence of a change in tillage practices on plant diseases in a crop, or cropping sequence, in a particular region cannot be assessed accurately without experimental data in that region. Some tillage practices may have a similar influence on certain pathogens all over the world; other practices may have a quite variable influence depending on the climate and cropping sequence. Phytotoxins from decomposing residues and allelopathy may be a limiting factor in using reduced tillage systems in some environments but not in others, and may also limit the use of crops in these systems.

In multiple-cropping systems in the subtropics and tropics, some disease control methods developed in monocrop systems may be satisfactory while others may have to be altered drastically. Certainly the principle of not planting closely related crops in succession to control diseases is valid, but it may be possible to plant the same or a similar crop (cucurbits, crucifers, beans) every year in a multiple-cropping system if one or two nonrelated crops are inserted between the related crops to alter the life cycles and the survival of pathogens. Integrated pest management systems using different tillage and pest control practices may allow growers the option of picking from numerous cropping systems depending on their interest, management abilities, and available markets.

Frequently, plant pathologists have not participated in research on the development of reduced tillage and multiple cropping systems. Plant pathologists, through their own initiative, need to work with scientists in other disciplines to determine the influence of tillage practices and cropping systems on plant diseases, bocause tillage changes so many factors simulta- 
neously, and plant disease control practices must be a part of a total crop production system. Growers need information available that will be useful in predicting the potential disease losses with different production practices. They then can make decisions to maximize profits, conserve soil and fuel, and at the same time provide adequate quantities of high quality food and fiber to moet the noeds of the world.

\section{Literature Cited}

1. All, J. N., Kuhn, C. W., Gallaher, R. N., Jellum, M. D., Hussey, R. S. 1977. Influence of notillage cropping, carbofuran, and hybrid resistance on dynamics of maize chlorotic dwarf and maize dwarf mosiac diseases of corn. $J$. Econ. Entomol. 70:221-25

2. American Society of Agricultural Engineers 1979. Terminology and definitions for soil tillage and soil-tool relationships. In Agriculture Engineers Yearbook, pp. 263-65. St. Josephs, Mich: Am. Soc. Agric. Eng. 740 pp.

3. Amin, K. S., Sequeira, L. 1966. Role of certain soil factors in the etiology of corky root rot of lettuce. Phytopathology 56:1047-53

4. Amon, B. O. E. 1965. The response by crops in a rotation to nitrogen, phosphorus, and potassium in the savannah zone of western Nigeria. In Proc. Oau/STRC, pp. 339-48. Symp. Maintenance Improvement Soil Fertility. London: Organ. Afr. Unity, Publ. No. 98. $473 \mathrm{pp}$.

5. Andrews, D. J., Kassam, A. H. 1976. The importance of multiple cropping in increasing world food supplies. In $\mathrm{Mul}$ tiple Cropping, pp. 1-10. ASA Spec. Publ. 27. Madison, Wis: Am. Soc. Agron. $378 \mathrm{pp}$.

6. Arny, D. C., Worf, G. L., Ahrens, R. W., Lindsey, M. F. 1970.' Yellow leaf blight of maize in Wisconsin: Its history and the reactions of inbreds and crosses to the inciting fungus (Phyllosticta sp.). Plant Dis. Reptr. 54:281-85

7. Baeumer, K., Bakerman W. A. P. 1973. Zero tillage. Adv. Agron. 25:78-123

8. Baker, K. F., Cook, R. J. 1974. Biological Control of Plant Pathogens. San Francisco: Freeman. 433 pp.

9. Beste, C. E. 1979. Notillage planted vegetable crops. 9th Int. Congr. Plant Prot., Aug. 5-11, Washington DC, Abstr. No. 136.

10. Boerma, H. R. 1979. Breeding for multicrop systems. See Ref. 9, Abstr. No. 685
11. Boosalis, M. G., Doupnik, B. Jr. 1976. Management of crop disease in reduced tillage systems. Entomol. Soc. Am. Bull. 22:300-2

12. Boosalis, M. G., Doupnik, B., Odvody, G. N. 1981. Conservation tillage in relation to plant diseases. In Handbook of Pest Management in Agriculture, Vol. 1, Boca Raton, Fla: CRC Press. 600 pp.

13. Boosalis, M. G., Scharen, A. L. 1959. Methods for microscopic detection of Aphanomyces euteiches and Rhizoctonia solani and for isolation of Rhizoctonia solani associated with plant debris. Phytopathology 49:192-98

14. Boosalis, M. G., Sumner, D. R., Rao, A. S. 1967. Overwintering of conidia of Helminthosporium turcicum on corn residue and in soil in Nebraska. Phytopathology 57:990-96

15. Boyd, H. W., Phillips, D. V. 1973. Toxicity of crop residue to peanut seed and Sclerotium rolfsii. Phytopathology 63: 70-71

16. Boyle, L. W. 1956. Fundamental concepts in the development of control measures for southern blight and root rot on peanuts. Plant Dis. Reptr. 40:661-65

17. Brinkerhoff, L. A. 1970 . Variation in Xanthomonas malvacearum and its relation to control. Ann. Rev. Phytopathol. 8:85-110

18. Brooks, D. H., Dawson, M. G. 1968. Influence of direct-drilling of winter wheat on incidence of take-all and eyespot. Ann. Appl. Biol. 61:57-64

19. Buddenhagen, I. W. 1965. The relation of plant-pathogenic bacteria to the soil. In Ecology of Soil-Borne Plant Pathogens, ed. K. F. Baker, W. C. Snyder, pp. 269-84. Berkeley \& Los Angeles: Univ. Calif. Press. 571 pp.

20. Buddenhagen, I. W., Kelman, A. 1964. Biological and physiological aspects of bacterial wilt caused by Pseudomonas solanacearum. Ann. Rev. Phytopathol. 2:203-30

21. Burke, D. W., Holmes, L. D., Barker, A. W. 1972. Distribution of Fusarium 
solani f. sp. phaseoli and bean roots in relation to tillage and soil compaction. Phytopathology 62:550-54

22. Burke, D. W., Miller, D. E., Holmes, L. D., Barker, A. W. 1972. Counteracting bean root rot by lossening the soil. Phytopathology 62:306-9

23. Bums, E. E., Shurtleff, M. C. 1973. Observations of Physoderma ma ydis in Illinois: Effects of tillage practices in field corn. Plant Dis. Reptr. 57:630-33

24. Chaudhary, M. R., Prihar, S. S. 1974. Root development and growth response of corn following mulching, cultivation, or interrow compaction. Agron. $J$. 66:350-55

25. Cochran, V. L., Elliott, L. F., Papendick, R. I. 1977. The production of phytotoxins from surface crop residues. Soil Sci. Soc. Am. J. 41:903-8

26. Cochrane, V. W. 1949. Crop residues as causative agents of root rots of vegetables. Conn. Agric. Exp. Stn. New Haven Bull. 526. 34pp.

27. Cook, R. J., Boosalis, M. G., Doupnik, B. 1978. Influence of crop residues on plant diseases. In Crop Residue Management Systems, pp. 147-63. Madison, Wis: Am. Soc. Agron. Spec. Publ. 31. $248 \mathrm{pp}$.

28. Cook, R. J., Waldher, J. T. 1977. Influence of stubble-mulch residue management on Cercosporella foot rot and yields of winter wheat. Plant Dis. Reptr. 61:96-100

29. Corbett, D. C. M., Webb, R. M. 1970. Plant and soil nematode population changes in wheat grown continuously in plowed and in unplowed soil. Ann. Appl. Biol. 65:327-35

30. Cox, R. W., Collins, F. C., Jones, J. P. 1976. Soybean seedling diseases associated with double cropping. Ark. Farm Res. 25:(3)5

31. Daft, G. C., Leben, C. 1973. Bacterial blight on soybeans: field-overwintered Pseudomonas gylcinea as possible primary inoculum. Plant Dis. Reptr. 57:156-57

32. Doupnik, B. Jr., Boosalis, M. G. 1980. Ecofallow- a reduced tillage systemand plant diseases. Plant Dis. 1:31-5

33. Doupnik, B. Jr., Boosalis, M. G., Wicks, G., Smika, D. 1975. Ecofallow reduces stalk rot in grain sorghum. Phytopathology 65:1021-22

34. Drayton, F. L. 1929. Bulb growing in Holland and its relation to disease control. Sci. Agric. 9:494-509

35. Ferrant, N. P., Carroll, R. B. 1979. Fusarium wilt of soybean and effect of tillage practices on occurrence of
Fusarium species in roots and soil. Phytopathology 69:534-35 (Abstr.)

36. Garren, K. H. 1962. Reaction of five peanut varieties to cultural control of stem rot. Phytopathology 52:1218 (Abstr.)

37. Gudmestad, N. C., Huguelet, J. E., Zink, R. T. 1978. The effect of cultural practices and straw incorporation into the soil on Rhizoctonia disease of potato. Plant Dis. Reptr. 62:985-89

38. Hartnett, J. P., Lorbeer, J. W. 1971. The production of a noninfectious lettuce root rot under controlled environmental and soil conditions. Phytopathology 61:1153-58

39. Hilty, J. W., Hadden, C. H., Garden, F. T. 1979. Response of maize hybrids and inbred lines to gray leaf spot disease and the effects on yield in Tennessee. Plant Dis. Reptr. 63:515-18

40. Hood, A. E. M. 1965. Plowless farming using "Gramoxone." Outlook Agric. 4(6):286-94

41. Horrocks, J. S. 1969. Influence of rape residue on cereal production. Can. J. Plant Sci. 49:632-34

42. Huber, D. M., McKay, H. C. 1968. Effect of temperature, crop, and depth of burial on the survival of Typhula idahoensis sclerotia. Phytopathology 58:961-62

43. Hussey, R. S., Roncadori, R. W. 1977. Vertical distribution of soil microorganisms following subsoiling in a cotton management system. Phytopathology 67:783-86

44. International Rice Research Institute. 1980. Annual Report 1979. Los Banos, Philippines: Int. Rice Res. Inst.

45. Janes, B. E., Drinkwater, W. O., Beall, G., Scarchuk, J., Lent, J. M. 1955. A 14 year study of vegetable crop rotations on a Merrinac fine sandy loam soil in Connecticut. Storrs Agric. Exp. Stn. Bull. 319. 55 pp.

46. Johnson, A. W., Sumner, D. R., Jaworski, C. A. 1979. Effects of management practices on nematode and fungus populations and cucumber yield J. Nematol. 11:84-93

47. Johnson, A. W., Sumner, D. R., Jaworski, C. A. 1979. Effect of film mulch, trickle irrigation, and DD-MENCS on nematodes, fungi, and vegetable yields in a multicrop production system. Phytopathology 69:1172-75

48. Johnston, H. W., Sanderson, J. B., MacLeod, J. A. 1978. Cropping mixtures of field peas and cereals in Prince Edward Island. Can. J. Plant Sci. 58:421-26 
49. Kelman, A., Cook, R. J. 1977. Plant pathology in the People's Republic of China. Ann. Rev. Phytopathol. 15: 409-29

50. Knavel, D. E., Ellis, J., Morrison, J. 1977. The effects of tillage systems on the performance and elemental absorption by selected vegetable crops. J. Am. Soc. Hortic. Sci. 102:323-27

51. Larios, J. F. 1976. Epifitiologia de algunas enfermedades foliares de la yuca (Manihot esculenta Craniz) en diferentes sistemas de cultivo. MS thesis UCR/CATIE, Turrialba, Costa Rica. $115 \mathrm{pp}$.

52. Larios, J., Moreno, R. 1976. Epidemiologia de algunas enfermedades foliares de la yuca en diferentes systemas de cultivo. I. Mildiu polvoroso y rona. Turrialba 26:389-98

53. Larios, J. F., Moreno, R. A. 1977. Epidemiologia de algunas enfermedades foliares de la yuca en diferentes sistemas de cultivo. II. Roya y muerte descendente. Turrialba 27:151-56

54. Ledingham, R. J., Sallans, B. J., Wenhardt, A. 1960. Influence of cultural practices on incidence of common root rot in wheat in Saskatchewan. Can. J. Plant Sci. 40:310-16

55. McCalla, T. M., Haskins, F. A. 1964. Phytotoxic substances from soil microorganisms and crop residues. Bacteriol. Rev. 28:181-207

56. Merriman, P. P., Pywell, M., Harrison, G., Nancarrow, J. 1979. Survival of sclerotia of Sclerotinia sclerotiorum and effects of cultivation practices on diseases. Soil Biol. Biochem. 11:567-70

57. Moreno, R. A. 1975. Diseminacion de Ascochyta phaseolorum en variedades de frijol de costa bajo diferentes sistemas de cultivo. Turrialba 25:361-64

58. Moreno, R. A. 1977. Effect of different cropping systems on the severity of angular leaf spot of bean (Phaseolus vulgaris L.), caused by Isariopsis griseola Sacc. Agron. Cost 1 (1):39-42

59. Moreno, R. A. 1979. Crop protection implication of cassava intercropping. Intercropping with Cossava. Proc. Int. Workshop, Trivandrum, India, 1978. 144 pp.

60. Mukhopadhyaya, M. C., Prasad, S. K. 1969. Nematodes as affected by rotations and their relation to feld crops. Indian J. Agric. Sci. 39:366-85

61. Mullins, C. A., Tompkins, F. D., Parks, W. L. 1980. Effects of tillage methods on soil nutrient distribution, plant nutrient absorption, stand, and yields of snap beans and lima beans. J. Am. Soc. Hortic. Sci. 105:591-93

62. Nasr, H. G. 1976. Multiple cropping in some countries of the Middle East. See Ref. 5, pp. 117-27

63. Natti, J. J. 1967. Overwinter survival of Pseudomonas phaseolicola in New York. Phytopathology 57:343-44 (Abstr.)

64. Newton, A. 1979. Multiple cropping from the viewers viewpoint. See Ref. 9, Abstr. No. 686

65. Odvody, G. N., Dunkle, L. D. 1973. Overwintering capacity of Ramulispora sorghi. Phytopathology 63:1530-32

66. Okigbo, B. N., Greenland, D. J. 1976. Intercropping systems in tropical Africa. See Ref. 5, pp. 63-101

67. Ou, S. H., Ling, K. C. 1969. Virus diseases of rice in the South Pacific. FAO Plant Prot. Bull. 14(5):113-21

68. Papavizas, G. C., Adams, P. B., Lumsden, R. D., Lewis, J. A., Dow, R. L., Ayers, W. A., Kantzes, J. G. 1975. Ecology and epidemiology of Rhizoctonia in field soil. Phytopathology 65:871-77

69. Parker, M. B., Minton, N. A., Brooks, O. L., Perry, C. E. 1975. Soybean yields and lance nematode populations as affected by subsoiling, fertility, and nematicide treatments. Agron. $J$. 67:663-66

70. Parker, M. B., Minton, N. A., Brooks, O. L., Perry, C. E. 1976. Soybean response to subsoiling and a nematicide. Ga. Agric. Exp. Stn. Res. Bull. 181. $22 \mathrm{pp}$.

71. Patrick, Z. A., Toussoun, T. A. 1965. Plant residues and organic amendments in relation to biological control. See Ref. 19, pp. 440-59

72. Patrick, Z. A., Toussoun, T. A., Snyder, W. C. 1963. Phytotoxic substances in arable soils associated with decomposition of plant residues. Phytopathology 53:152-61

73. Phillips, R. E., Blevins, R. L., Thomas, G. W., Frye, W. W., Phillips, S. H. 1980. No-tillage agriculture. Science 208:1108-13

74. Pinchinat, A. M., Soria, J., Bazan, R 1976. Multiple cropping in tropical America. See Ref. 5, pp. 51-61

75. Plucknett, D. L., Everson, J. P., Sanford, W. G. 1970. Ratoon cropping. Adv. Agron. 22:285-330

76. Roane, C. W., Harrison, R. L., Genter, C. F. 1974. Observations on gray leaf spot of maize in Virginia. Plant Dis. Reptr. 58:456-59 
77. Rohde, W. A., Johnson, A. W., Dowler, C. C., Glaze, N. C. 1980. Influence of climate and cropping pattern on the effcacy of ethoprop, methyl bromide, and DD-MENCS for control of root-knot nematodes. J. Nematol. 12:33-39

78. Schaad, N. W., White, W. C. 1974. Survival of Xanthomonas campestris in soil. Phytopathology 64:1518-20

79. Schuster, M. L. 1975. Leaf freckles and wilt of com incited by Corynebacterium nebraskense Schuster, Hoff, Mandel, Lazar. 1972. Nebr. Agric. Exp. Stn. Res. Bull. 27040 pp.

80. Schuster, M. L., Coyne, D. P. 1974. Survival mechanisms of phytopathogenic bacterial. Ann. Rev. Phytopathol. 12:199-221

81. Sewell, G. W., Wilson, J. F. 1974. The influence of normal tillage and noncultivation on Verticillium wilt of the hop. Ann. Appl. Biol. 76:37-47

82. Shipton, P. J. 1974. Monoculture and soilborne plant pathogens. Ann. Rev. Phytopathol. 15:387-407

83. Sitterly, W. R. 1969. Eff ect of crop rotation on cucumber gummy stem blight. Plant Dis. Reptr. 53:417-19

84. Smittle, D. A., Threadgill, E. D. 1977. Response of southern pea [Vigna unguiculata (L.) Walp] to tillage methods. Hortic. Sci 12:556-58

85. Soil Conservation Society of America. 1976. Resource Conservation Glossary. Ankeny, Iowa: Soil Conserv. Soc. Am. $63 \mathrm{pp}$.

86. Southards, C. J. 1971. Effect of fall tillage and selected hosts on the population density of Meloidogyne incognita and Pratylenchus zeae. Plant Dis. Reptr. 55:41-44

87. Standifer, L. C., Ismail, M. N. B. 1975. A multiple cropping system for vegetable production under subtropical, high rainfall conditions. J. Am. Soc. Hortic. Sci. 100:503-6

88. Sumner, D. R., Bell, D. K. 1980 . Root diseases of corn caused by Rhizoctonia solani and Rhizoctonia zeae. Phytopathology 70:572 (Abstr.)

89. Sumner, D. R., Bell, D. K., Huber, D. M. 1979. Pathology, host range, and ecology of a sterile basidiomycete causing root disease on corn. Plant Dis. Reptr. 63:981-85

90. Sumner, D. R., Dowler, C. C., Johnson, A. W., Chalfant, R. B. 1978. Root diseases of corn in an integrated pest management system. 3rd Int. Congr. Plant Pathol, Munchen, 16-23 Aug. Abstr. Papers. p. 176 (Abstr.)
91. Sumner, D. R., Glaze, N. C., Dowler, C. C., Johnson, A. W. 1978. Foliar diseases of turnip grown for greens in intensive cropping systems. Plant Dis. Reptr. 62:51-55

92. Sumner, D. R., Glaze, N. C., Dowler, C. C., Johnson, A. W. 1979. Herbicide treatments and root diseases of tumip in intensive cropping systems. Plant Dis. Reptr. 63:801-5

93. Sumner, D. R., Johnson, A. W., Glaze, N. C., Chalfant, R. B., Dowler, C. C. 1979. Root diseases of southern pea (Vigna unguiculata) in an integrated pest management system. Phytopathology 69:1046 (Abstr.)

94. Sumner, D. R., Johnson, A. W., Glaze, N. C., Dowler, C. C. 1975. Disease, nematode, and weed control in intensive cropping systems. Ga. Agric. Res. 16(4):4-5,7

95. Sumner, D. R., Johnson, A. W., Glaze, N. C., Dowler, C. C. 1978. Root diseases of snapbean and southern pea in intensive cropping systems. Phytopathology 68:955-61

96. Sumner, D. R., Littrell, R. H. 1974. Influence of tillage, planting date, inoculum survival, and mixed populations on epidemiology of southern com leaf blight. Phytopathology 64:168-73

97. Sumner, D. R., Smittle, D. A. 1979. Influence of chlorothalonil, nitrogen, and tillage practices on Cercospora leafspots and rust in southern pea [Vigna unguiculata (L.) Walp]. Hortic. Sci. 14:266-68

98. Sumner, D. R., Smittle, D., Threadgill, E. D. 1977. Influence of tillage practices on root diseases of southern pea (Vigna unguiculata). Ann. Rep. Bean Imp. Coop. 20:91-93

99. Sumner, D. R., Threadgill, E. D., Dowler, C. C., Phatak, S. C., Smittle, D., Young, J., Mitchell, G. A., Johnson, A. W. 1980. Tillage practices, populations of soil fungi, and root diseases in irrigated, multiple cropping sequences. Phytopathology 71:259 (Abstr.)

100. Tanasevych, I. I., Korobil, I. A. 1978. Effect of preceding crops and method of soil tillage on the rate of winter wheat infections with root rot in the western forest-steppe in the Ukrainian SSR. Zakhyst Roslyn. 25:3-7 (From 1980. Rev. Plant Pathol. 58:141)

101. Thomas, S. H. 1978. Population densities of nematodes under seven tillage regimes. J. Nematol. 10:24-27

102. Trenbath, B. R. 1976. Plant interactions in mixed crop communities, See Ref. 5, pp. 129-64 
103. Tuleen, D. M., Frederiksen, R. A., Vudhivanich, P. 1980. Cultural practic and the incidence of sorghum downy mildew in grain sorghum. Phytopathology 70:905-8

104. Van Wijh, W. R., Larson, W. E., Burrows, W. E. 1959. Soil temperature and the early growth of com from mulched and unmulched soil. Soil Sci. Soc. Am. Proc. 23:428-34

105. Webster, R. K., Bolstad, J., Wick, D. M., Hall, D. H. 1976. Vertical distribution and survival of Sclerotium oryzae under various tillage methods. Phytopathology 66:97-101

106. White, D. G., Yanney, J., Natti, T. A. 1979. Anthracnose stalk rot. Proc. Ann. Corn Soybean Res. Conf. 34:1-16

107. Wi e, M. V., Ravenscroft, A. V. 1975.
Cephalosporium gramineum populations in soil under winter wheat cultivation. Phytopathology 65:1129-33

108. Will, A. G. K. 1968. A system of vegetable crop rotation in Uganda. East Afr. Agric. For. J. 34:217-23

109. Williams, P. H. 1979. Vegetable crop protection in the Peoples Republic of China. Ann. Rev. Phytopathol. 17: 311-24

110. Wittmus, H., Olson, L., Lene, D. 1975. Energy requirements for conventional versus minimal tillage. J. Soil Water Conserv. 30:72-75

111. Worley, R. E., Morton, D. J., Harmon, S. A. 1966. Reduction of southern blight on tomato by deep plowing. Plant Dis. Reptr. 50:443-44 